\author{
KADIR TEMURÇIN \\ Süleyman Demirel University, Isparta, Turkey \\ YolCU ALDIRMAZ \\ Süleyman Demirel University, Isparta, Turkey
}

\title{
The Structure, Development and Spatial Distribution of Industrial Activities in Turkey
}

\begin{abstract}
This study deals with the development of industry which is one of the most important elements of socio-economic transformation in Turkey, its structural features, spatial distribution, as well as the factors that influence it. Industrialization movements started in Turkey in 1963 with planned development moves and accelerated as a result of the impact of liberal policies implemented, in and after the year 1980. Initially, industrial activities concentrated in metropolitan areas and subsequently started to expand to other areas in the country, in time with a view on regional development as a result of factors such as development plans, applied initiative policies, current raw material resources and transport. However, there are still major disparities in the distribution of the manufacturing industry, enterprises, employees, exporting and importing within the country. In fact, according to data for $2014,43.9 \%$ of manufacturing industrial enterprises and $47.4 \%$ of employees are concentrated in the Marmara Region. The Marmara Region is followed by the Central Anatolian Region with $13.8 \%$ and $15.3 \%$ and the Aegean Region with $14 \%$ and $15.2 \%$ in terms of manufacturing industrial enterprises and employees respectively. Furthermore, $69.7 \%$ of exports and $76.9 \%$ of imports are processed in the Marmara Region which is followed by $9.6 \%$ and $7.7 \%$ in the Aegean Region and $8.2 \%$ and $7.4 \%$ in the Central Anatolian Region respectively. In terms of provinces, industry is concentrated in Istanbul, Izmir, Ankara, Bursa, Konya, Gaziantep, Antalya, Adana, Kocaeli and Denizli in Turkey. These provinces consist of $64 \%$ of enterprises and $65.7 \%$ of employees in Turkey. Data acquired from Turkish Statistical Institute (Turkstat) and the Ministry of Science, Industry and Technology has been assessed with the use of ArcGis program.
\end{abstract}

Keywords: historical development; industrialization; manufacturing; spatial distribution; Turkey

Received: 26 December 2016

Accepted: 30 October 2017

\section{Suggested citation:}

Temurçin, K., Aldirmaz, Y. (2017). The Structure, Development and Spatial Distribution of Industrial Activities in Turkey. Prace Komisji Geografii Przemysłu Polskiego Towarzystwa Geograficznego [Studies of the Industrial Geography Commission of the Polish Geographical Society], 31(4), 52-70. https://doi. org/10.24917/20801653.314.4 


\section{INTRODUCTION}

The fortification of industrial activities which had rather receded in the final era of the Ottoman Empire and which had endeavored to be developed as of the declaration of the republic in Turkey (Figure 1) but which had failed due to reasons such as technical inadequacies, erroneous policies, ignorance, wars and internal conflicts have become one of the fundamental policies (Doğan 2013; Tümertekin 1959; Clark 1992; Wiener 1992). The Izmir Economy Congress organized on 17 February 1923 is the first initiative in this area. With the decisions taken at the congress the state became the protector and organizer of economic activities. Furthermore, İş Bankası was established in 1924 and the Sanayi ve Maadin Bank was established in 1925 to fortify private capital. Various promotions were granted to private enterprises with the Industrial Promotion Law enacted in 1927 (Özgüç 1986-1987). These activities accelerated the industrialization process in Turkey (Ardel 1943). Therefore, according to the industrial statistics for 1921, 51,491 individuals were employed by 33,162 enterprises in the country while these figures reached 256,855 individuals in 65,245 enterprises in 1927 (Figures 2 and 3). Furthermore, while the ratio of employees ratio of employees to workplaces was 2.53 in 1921 this value increased to 3.94 in 1927 (İlgen 2008; DIE 1969). The change in ratio does not only depict the increase in the number of employees and enterprises during 1921-1927, it also reflects the expansion trend of the enterprises.

Until 1950 no census has been carried out regarding the enterprises, outside the scope of the Industrial Promotion Law from 1927 when the industry census was carried out, and therefore the development of industry during this period could not be monitored (Cillov 1970; Cillov 1954). On the other hand the failure of applied policies until 1933 to become successful and the 'liberal policy' applied during 1923-1933 due to reasons such as the Economic Depression of 1929 have been abandoned and a 'pro-state policy' has been applied during 1933-1950. During his same period the state established its own enterprises in the areas in which the private sector was inadequate or granted significant support to the private sector for the establishment of enterprises. For example, the state

Figure 1. Map of Turkey regions and provinces

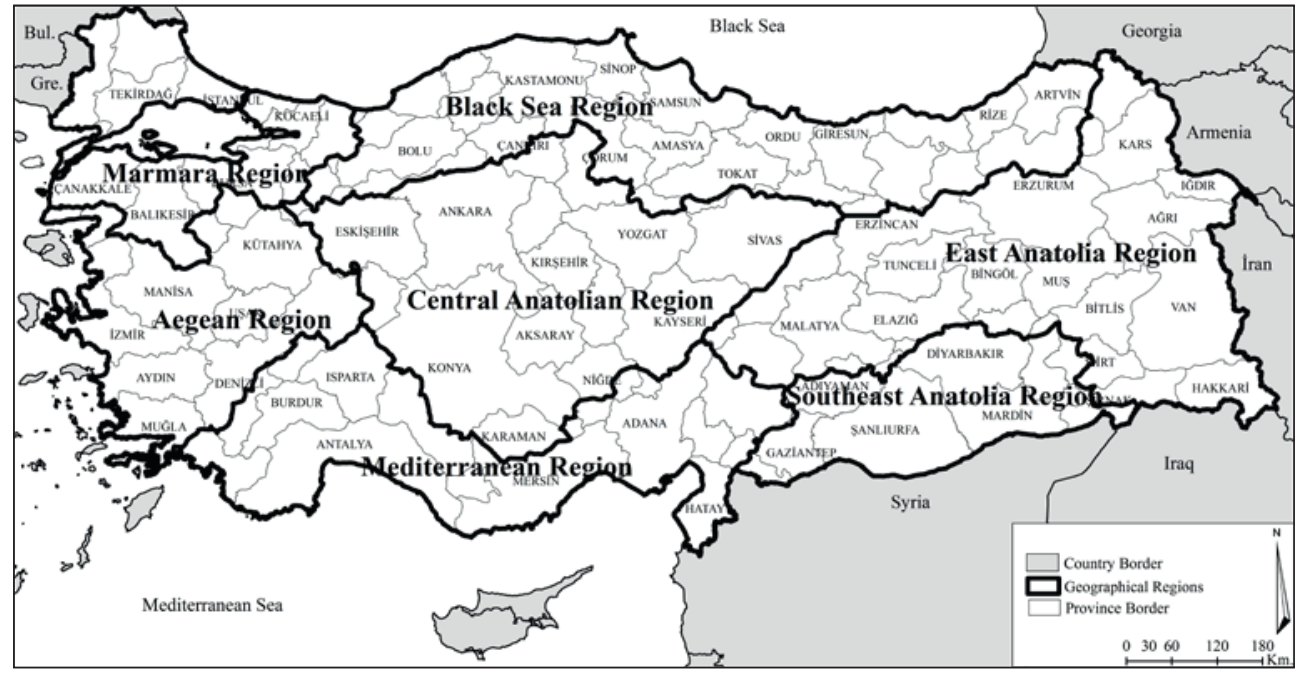


has made direct investments in every area in the country, with sugar factories in particular (Sevgi 1994; Karluk 1999; Şahin 2000; Avcı 1996; Altıparmak 2002; Tekeli and İlkin 2009). As a result of the aforementioned investments the number of enterprises reached 98,828 and the number of employees reached 353,994 in 1950 (Figures 2 and 3).

The development in industrialization also manifested itself in the industry census carried out in 1964 as a result of the second liberal policy applied between the years 1950-1960 which promoted foreign capital and the private sector, limited import with a quota system and development plans applied as of 1963 (Yücel 2015; Şener 2005; Çam 1984; Özgüç 1986-1987; Kerwin 1951; Avcı 2000). The number of enterprises reached 160,771 and the number of employees reached 679,462 in 1964 (Figures 2 and 3).

The fact that as of the 1960s all the planned development strategies applied in Turkey have adopted industrialization as a priority area, that it is viewed as the basis of economic development, efforts to apply liberal economy policies more seriously and the targeting of decreasing the number of state sector enterprises has ensured significant contributions to industrialization in Turkey during certain periods (Doğanay 2011; Ünal 2011). The increases generated in the manufacturing industry during 1970s and 1980 s are the results of the above developments. Furthermore, the number of enterprises and employees which was 175,299 and 837,499 respectively in 1970 increased to 185,869 and 1,289,325 respectively in 1980 (Figures 2 and 3).

After 1980 the introverted economy policy which had been applied since 1960 was abandoned, an industrial policy aiming at exports was adopted and significant developments in the area of industrialization took place (Yaşar 2004; Tonus 2007; Soyyiğit 2010; Celasun 1994; DPT 2003). The results of the industry census carried out as of this period support the above mentioned statement. The number of enterprises which was 193,753 in 1985 increased to 198,098 in 1992 and 272,482 in 2002. The increase in the number of enterprises has been proportionally reflected in the number of employees which was 1,463,176 in 1985 and increased to 1,508,039 in 1992 and 2,183,286 in 2002 (Figures 2 and 3).

During the past 12 years industry in Turkey has continued to develop with the exception of the decline in the number of employees in 2009 and the decline in the number of businesses in 2010 which incurred as a result of the crisis in 2008. Currently with a total of 427,584 work places and 3,628,324 employees Turkey is among the "Emerging Industrial Economies" in the world. Furthermore the added value from manufacturing industry products increased by 224\% between 2003 and 2014 to reach 84.5 billion dollars, while the manufacturing value increased by $291 \%$ to a total of 437.3 billion dollars (Table 1). With the mentioned growth Turkey ranks 15 th in the world in terms of added value in 2014. In terms of manufacturing industry export numbers the country was ranked 32nd in 2002 and 25th in 2014. Furthermore, while the country was ranked 20th according to the global manufacturing competitiveness index for 2013 its ranking changed to 16th place in 2016 due to low tax rates, abundant and qualified work force potential, strategic position, comprehensive commercial network and policies which support competitiveness. In addition as a result of the long term studies carried out for the establishment of private capital, many international companies based in Turkey are making serious investments in other areas in the world and these investments are very much prioritized by the relevant countries (UNIDO 2013; Turkstat; UNIDO 2015; Ministry of Development 2014; Deloitte 2013; Deloitte 2016; Thailand Board Of Investment WTO). 
Figure 2. Historical development of industrial enterprises in Turkey

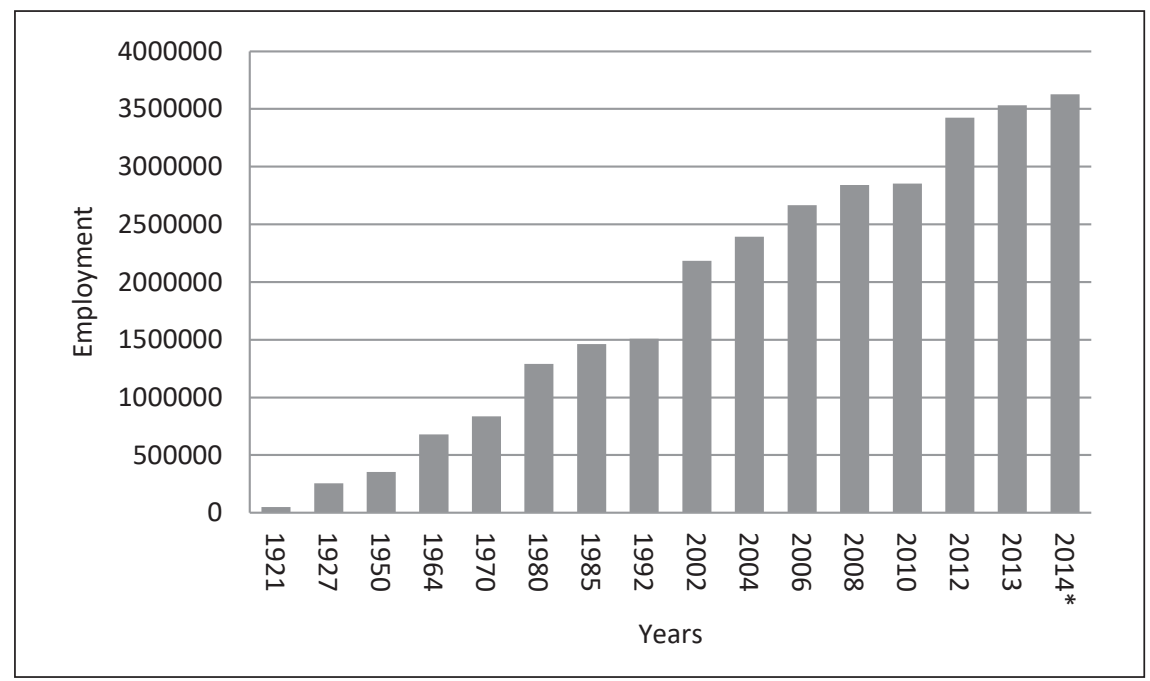

Source: DIE, Turkstat

*Data not finalized

Figure 3. Historical development of the number of employees in the Turkish industry

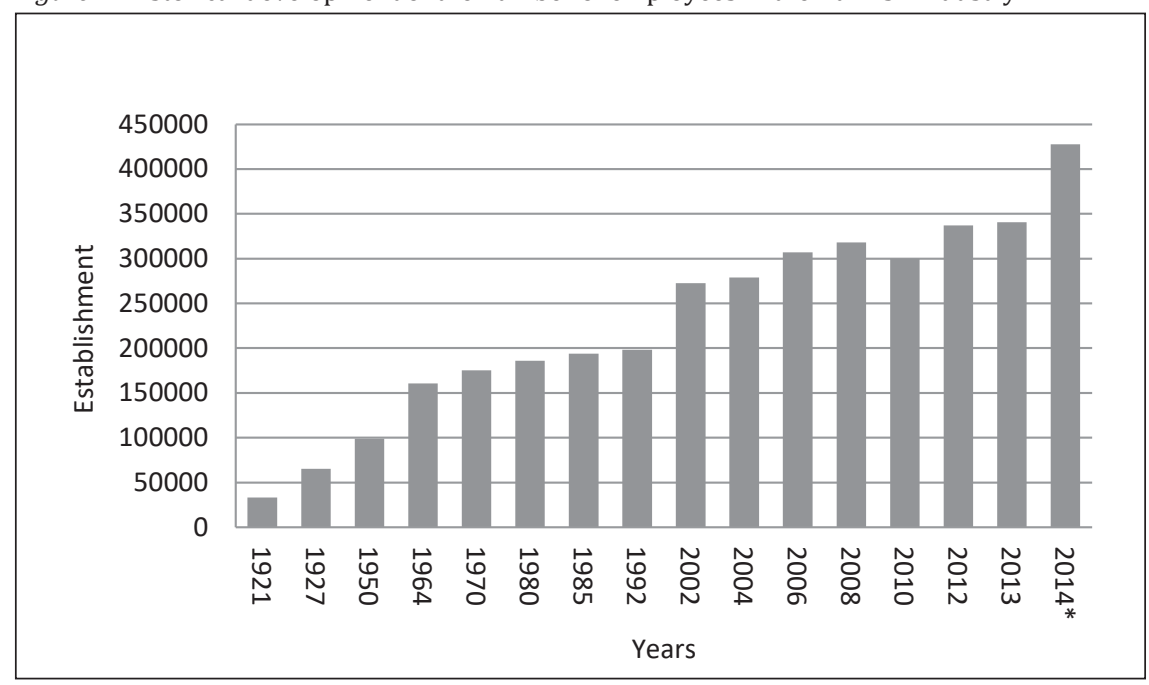

Source: DIE, Turkstat

*Data not finalized

This study, dealing with the development, structure and spatial distribution of industry in Turkey, is comprised of three parts. The preamble introduces the development of industry in the country with a view on the conditions at the time and the applied policies. The second part deals with the changes which incurred in the structure of industry. The final part consists of the spatial distribution and transformation of industrial activities. All industry censuses carried out during the republican era including the industry census carried out in 1921 have been used in the study. The main problem 
Table 1. Added value and production value amount of manufacturing industry in Turkey

\begin{tabular}{|l|c|c|c|c|c|}
\hline Years & $\begin{array}{c}\text { Production Value } \\
\text { (Billion \$) }\end{array}$ & $\begin{array}{c}\text { Added Value } \\
\text { (Billion \$) }\end{array}$ & Years & $\begin{array}{c}\text { Production Value } \\
\text { (Billion \$) }\end{array}$ & $\begin{array}{c}\text { Added Value } \\
\text { (Billion \$) }\end{array}$ \\
\hline $2003^{*}$ & 150.2 & 37.7 & $2009^{* *}$ & 271.7 & 54.8 \\
\hline $2004^{*}$ & 200.7 & 47.1 & $2010^{* *}$ & 349.6 & 66.1 \\
\hline $2005^{* *}$ & 232.6 & 44.9 & $2011^{* *}$ & 417.0 & 77.2 \\
\hline $2006^{* *}$ & 265.0 & 52.3 & $2012^{* *}$ & 418.6 & 74.0 \\
\hline $2007^{* *}$ & 318.7 & 60.7 & $2013^{* *}$ & 476.5 & 90.7 \\
\hline $2008^{* *}$ & 369.0 & 72.6 & $2014^{* *}$ & 437.3 & 84.5 \\
\hline
\end{tabular}

* The currency for the calculation taken from Central Bank of the Republic of Turkey.

** The currency for the calculation taken from General Directorate of Budget and Fiscal Control (BUMKO).

Source: TUIK

of the study was that the industry censuses had been carried out with various scopes during each period instead of a single standard. In order to eliminate the impact of this feature the scopes of all industry censuses were studied in detail and the assessments were made according to the characteristics of each standard. Furthermore, priority has been given to the assessment of data generated according to equal standards during the past 12 years and more consideration has been given to this data in the interpretations. Moreover, province-based assessments have been made by prioritizing the employment criterion. The objective has been to eliminate the gaps generated by the pairing of enterprises which are continuously downsizing as a result of the decentralization processes which have been prominent especially during the last 35 years, as well as large enterprises. The acquired data has been mapped using an ArcGis program to ensure a better understanding of the subject.

\section{STRUCTURAL CHANGE OF INDUSTRY IN TURKEY}

The rapid development of industrial activities in Turkey has been accompanied by a simultaneous growth in enterprises (Özgüç 1986-1987). In 1970, 99.2\% of enterprises, in $1980,98.9 \%$ of enterprises, in 2002 and $2009,97.9 \%$ of enterprises and in 2013, $97 \%$ of enterprises employed 49 or fewer employees. Likewise the number of enterprises hiring 1000 and more employees was 79 in 1970, 126 in 1980, 163 in 2009 and reached 241 in 2013. The number of enterprises employing 5000 and more employees has risen from 11 to 16 within the past four years (Table 2). Furthermore, a significant change has taken place in the distribution of total employment and the size of enterprises in terms of years. The ratio of enterprises which qualify as SMEs ${ }^{1}$ and employ less than 250 people (as opposed to minor decreases in the recent past) comprise $99.81 \%$ of total enterprises (Table 3). However, when the position of these enterprises in terms of manufacturing industry activities is studied for manufacturing value and added value criteria a totally different situation emerges. Moreover it is evident that large companies have more production value and added value. According to data for 2013, enterprises which employ less than 250 individuals counter 46.1 of total production and $44.7 \%$ of added value. On the other hand enterprises which employ 1000 and more individuals and comprise only 0.07 of all enterprises generate $29.2 \%$ of production value and $28.4 \%$ of added value (Tables 4 and 5 ).

\footnotetext{
${ }^{1}$ Small and medium-sized enterprises
} 
Table 2. Distribution of enterprises according to the size of the workplace

\begin{tabular}{|l|c|c|c|c|c|c|c|c|c|c|}
\hline \multirow{2}{*}{ Size } & 2009 & $\%$ & 2010 & $\%$ & 2011 & $\%$ & 2012 & $\%$ & 2013 & $\%$ \\
\cline { 2 - 12 } & 320.815 & 100.00 & 299.928 & 100.00 & 333.288 & 100.00 & 336.893 & 100.00 & 340.438 & 100.00 \\
\hline $1-19$ & 304.373 & 94.87 & 278.180 & 92.75 & 308.700 & 92.62 & 309.818 & 91.96 & 312.352 & 91.75 \\
\hline $20-49$ & 9.572 & 2.98 & 13.796 & 4.60 & 15.760 & 4.73 & 17.427 & 5.17 & 17.808 & 5.23 \\
\hline $50-99$ & 3.279 & 1.02 & 3.874 & 1.29 & 4.299 & 1.29 & 4.752 & 1.41 & 5.073 & 1.49 \\
\hline $100-249$ & 2.434 & 0.76 & 2.780 & 0.93 & 3.062 & 0.92 & 3.315 & 0.98 & 3.525 & 1.04 \\
\hline $250-499$ & 705 & 0.22 & 783 & 0.26 & 910 & 0.27 & 986 & 0.29 & 1.045 & 0.31 \\
\hline $500-999$ & 289 & 0.09 & 329 & 0.11 & 358 & 0.11 & 371 & 0.11 & 394 & 0.12 \\
\hline $1000-4999$ & 152 & 0.05 & 176 & 0.06 & 186 & 0.06 & 209 & 0.06 & 225 & 0.07 \\
\hline $5000+$ & 11 & 0.003 & 10 & 0.003 & 13 & 0.004 & 15 & 0.004 & 16 & 0.005 \\
\hline
\end{tabular}

Source: Turkstat

Table 3. Employment by the size of the workplace

\begin{tabular}{|c|c|c|c|c|c|c|c|c|c|c|}
\hline \multirow{2}{*}{ Size } & 2009 & $\%$ & 2010 & $\%$ & 2011 & $\%$ & 2012 & $\%$ & 2013 & $\%$ \\
\hline & 2.584 .773 & 100.00 & 2.852 .352 & 100.00 & 3.151 .019 & 100.00 & 3.423 .468 & 100.00 & 3.530 .977 & 100.00 \\
\hline $1-19$ & 879.382 & 34.02 & 848.324 & 29.74 & 909.258 & 28.86 & 978.859 & 28.59 & 944.097 & 26.74 \\
\hline $20-49$ & 318.414 & 12.32 & 445.177 & 15.61 & 501.509 & 15.92 & 550.983 & 16.09 & 562.583 & 15.93 \\
\hline $50-99$ & 230.280 & 8.91 & 267.646 & 9.38 & 296.056 & 9.40 & 326.591 & 9.54 & 350.513 & 9.93 \\
\hline $100-249$ & 368.468 & 14.26 & 422.785 & 14.82 & 468.035 & 14.85 & 506.390 & 14.79 & 541.335 & 15.33 \\
\hline 250-499 & 241.643 & 9.35 & 266.607 & 9.35 & 311.986 & 9.90 & 338.323 & 9.88 & 358.917 & 10.16 \\
\hline 500-999 & 199.128 & 7.70 & 223.534 & 7.84 & 244.825 & 7.77 & 254.761 & 7.44 & 269.378 & 7.63 \\
\hline 1000-4999 & 256.098 & 9.91 & 299.053 & 10.48 & 320.085 & 10.16 & 356.136 & 10.40 & 385.513 & 10.92 \\
\hline $5000+$ & 91.360 & 3.53 & 79.226 & 2.78 & 99.265 & 3.15 & 111.425 & 3.25 & 118.641 & 3.36 \\
\hline
\end{tabular}

Source: Turkstat

Table 4. Production value by the size of the workplace (Billion \$)

\begin{tabular}{|l|c|c|c|c|c|c|c|c|c|c|}
\hline \multirow{2}{*}{ Size } & 2009 & $\%$ & 2010 & $\%$ & 2011 & $\%$ & 2012 & $\%$ & 2013 & $\%$ \\
\cline { 2 - 12 } & 271.7 & 100.00 & 349.6 & 100.00 & 417.0 & 100.00 & 418.6 & 100.00 & 476.5 & 100.00 \\
\hline $1-19$ & 36.8 & 13.54 & 40.1 & 11.46 & 42.3 & 10.14 & 41.0 & 9.79 & 49 & 10.27 \\
\hline $20-49$ & 27.0 & 9.94 & 41.9 & 11.98 & 50.0 & 11.99 & 50.8 & 12.13 & 56 & 11.68 \\
\hline $50-99$ & 22.1 & 8.13 & 29.8 & 8.51 & 35.1 & 8.41 & 37.1 & 8.86 & 41 & 8.52 \\
\hline $100-249$ & 41.9 & 15.43 & 53.5 & 15.30 & 62.3 & 14.94 & 63.5 & 15.18 & 74 & 15.60 \\
\hline $250-499$ & 34.4 & 12.65 & 41.9 & 11.99 & 52.5 & 12.59 & 52.1 & 12.45 & 61 & 12.81 \\
\hline $500-999$ & 35.5 & 13.05 & 43.5 & 12.43 & 52.0 & 12.46 & 50.1 & 11.98 & 57 & 11.97 \\
\hline $1000-4999$ & 55.0 & 20.22 & 74.7 & 21.37 & 91.8 & 22.01 & 92.1 & 22.00 & 101 & 21.29 \\
\hline $5000+$ & 19.1 & 7.04 & 24.3 & 6.96 & 31.0 & 7.44 & 31.9 & 7.61 & 38 & 7.87 \\
\hline
\end{tabular}

Source: Turkstat

Table 5. Added value according to the size of the workplace (Billion \$)

\begin{tabular}{|l|r|r|r|r|r|r|r|r|r|r|}
\hline \multirow{2}{*}{ Size } & \multicolumn{1}{|c|}{2009} & \multicolumn{1}{c|}{$\%$} & \multicolumn{1}{c}{2010} & \multicolumn{1}{c}{$\%$} & \multicolumn{1}{c}{2011} & \multicolumn{1}{c}{$\%$} & \multicolumn{1}{c}{2012} & $\%$ & 2013 & $\%$ \\
\cline { 2 - 12 } & 54.8 & 100.00 & 66.1 & 100.00 & 77.2 & 100.00 & 74.0 & 100.00 & 90.7 & 100.00 \\
\hline $1-19$ & 6.1 & 11.10 & 6.9 & 10.38 & 6.6 & 8.58 & 7.3 & 9.83 & 8.0 & 8.85 \\
\hline $20-49$ & 5.0 & 9.17 & 7.0 & 10.55 & 8.4 & 10.81 & 8.6 & 11.68 & 10.1 & 11.09 \\
\hline $50-99$ & 4.2 & 7.65 & 5.1 & 7.78 & 6.0 & 7.72 & 6.1 & 8.29 & 7.7 & 8.47 \\
\hline
\end{tabular}




\begin{tabular}{|l|r|r|r|r|r|r|r|r|r|r|}
\hline $100-249$ & 8.6 & 15.63 & 9.9 & 14.99 & 11.7 & 15.15 & 11.7 & 15.87 & 14.7 & 16.25 \\
\hline $250-499$ & 7.3 & 13.32 & 8.3 & 12.49 & 10.5 & 13.56 & 9.8 & 13.25 & 12.5 & 13.83 \\
\hline $500-999$ & 7.7 & 13.97 & 8.2 & 12.33 & 10.1 & 13.10 & 8.9 & 12.09 & 11.9 & 13.11 \\
\hline $1000-4999$ & 12.4 & 22.61 & 15.2 & 22.98 & 17.5 & 22.61 & 15.8 & 21.40 & 18.3 & 20.13 \\
\hline $5000+$ & 3.6 & 6.56 & 5.6 & 8.50 & 6.5 & 8.45 & 5.6 & 7.60 & 7.5 & 8.28 \\
\hline
\end{tabular}

Source: Turkstat

As indicated by the foregoing statements large companies hold a rather significant position in the economy of Turkey. However, the spatial distribution of these companies has an irregular pattern. This irregularity in distribution is clearly manifested by the distribution of the one thousand largest companies determined by the Istanbul Chamber of Commerce. These one thousand companies are active in 57 provinces in different regions in Turkey and the remaining 24 provinces host none of these 1000 large companies. A province-based distribution of enterprises and employees indicates that Istanbul province ranks in first place with 38.4\%. In terms of enterprises, Istanbul province is followed by Izmir, Bursa, Kocaeli, Ankara, Gaziantep, Kayseri, Adana, Konya, and Denizli provinces, while the list of provinces in terms of employee numbers continues with Ankara, Bursa, Gaziantep, Izmir, Kocaeli, Manisa, Zonguldak, Kayseri, and Adana provinces. These listed provinces host $78.6 \%$ of the 1000 large industrial enterprises which employ $79.8 \%$ of the employees employed by these enterprises. These provinces have significant advantages in terms of many development related factors such as industrial infrastructures, geographical position, characteristics, positive advantages for industrialization, central positions in the periphery, transport opportunities, internal and external market opportunities, qualified labour, education and health (Temurçin 2015).

\section{SPATIAL TRANSFORMATION OF INDUSTRY IN TURKEY}

A major part of the industrial policies applied in Turkey aim at the equal development of manufacturing activities in a regional sense or the elimination of existing inequalities (Dinler 2005) As a result, in spite of the aforementioned policies and the significant changes in the spatial distribution of industrial activities there are still some serious disparities in Turkey in this regard. However, a transformation in a spatial sense has been ongoing recently. Between the years 2002-2014 an increase of 29.6\% in the number of employees and $36.3 \%$ in the number of enterprises has taken place in Turkey. The regions with the highest number of increased enterprises are listed as Southeast Anatolia, Marmara, East Anatolia, while the regions with the highest increase in employment are Central Anatolia, Southeast Anatolia, and the Mediterranean regions. Furthermore, the share of Marmara, Southeast Anatolia, and East Anatolia in terms of the distribution of total enterprises increased between the years 2002-2014, whereas the share of other regions decreased. On the other hand, Marmara and the Black Sea regions were the only regions which had an increased share in total employment (Table 6).

When the change briefly indicated above is considered on a province scale it is possible to gain more information, as well as it is possible to have a more detailed study of the spatial irregularities. The mentioned irregularities are manifested in two forms. The first irregularity is that the number of enterprises still has a tendency to concentrate in 
Table 6. Regional distribution of manufacturing industry establishments and employment in Turkey

\begin{tabular}{|l|c|r|r|r|r|r|r|r|}
\hline \multirow{2}{*}{ Regions } & \multicolumn{2}{|c|}{2002} & \multicolumn{2}{c|}{2014} & \multicolumn{2}{c|}{2002} & \multicolumn{2}{c|}{2014} \\
\cline { 2 - 9 } & Establishment & \multicolumn{1}{c|}{$\%$} & Establishment & \multicolumn{1}{c|}{$\%$} & Employment & $\%$ & \multicolumn{1}{c|}{ Employment } & $\%$ \\
\hline Mediterranean & 30,370 & 11.15 & 44,103 & 10.31 & 155,659 & 7.13 & 241,399 & 7.78 \\
\hline East Anatolia & 11,364 & 4.17 & 18,415 & 4.31 & 49,503 & 2.27 & 70,688 & 2.28 \\
\hline Aegean & 46,386 & 17.02 & 60,067 & 14.05 & 330,303 & 15.13 & 472,110 & 15.22 \\
\hline $\begin{array}{l}\text { Southeast } \\
\text { Anatolia }\end{array}$ & 14,189 & 5.21 & 26,477 & 6.19 & 87,608 & 4.01 & 152,563 & 4.92 \\
\hline $\begin{array}{l}\text { Central } \\
\text { Anatolia }\end{array}$ & 40,262 & 14.78 & 59,141 & 13.83 & 264,713 & 12.12 & 474,421 & 15.30 \\
\hline Black Sea & 26,261 & 9.64 & 31,722 & 7.42 & 162,822 & 7.46 & 220,489 & 7.11 \\
\hline Marmara & 103,650 & 38.04 & 187,659 & 43.89 & $1,132,678$ & 51.88 & $1,469,875$ & 47.39 \\
\hline Total & 272,482 & 100 & 427,584 & 100 & $2,183,286$ & 100 & $3,101,545$ & 100 \\
\hline
\end{tabular}

Source: Turkstat

certain regions. The other irregularity is that employment is gradually shifting outside the areas where industry has been concentrated in the past. Indeed, while the first ten provinces with the highest concentration of industry hosted $59.5 \%$ of total enterprises in 2002 this rate had increased to $64 \%$ in 2014. On the other hand, while the first ten provinces comprised $69.7 \%$ of total employment in 2002, this was countered by $65.7 \%$ in 2014. One of the fundamental reasons for change is that with the decentralization processes of the areas in which industry have been concentrated in the past, large enterprises are shifting towards their perimeters, as well as the availability of conditions for small scale enterprises which are not subjected to decentralization to remain in urban areas. Therefore, enterprises which ensure more employment are shifting towards newly industrialized zones and even if these zones do not accommodate large numbers of enterprises, they ensure the rapid development of industry in terms of employment. In the meantime enterprises within urban areas continue to downsize and transform into a structure in which each product is manufactured in different facilities and compiled in a single unit. The indicated process increases the number of enterprises however, since it cannot generate the employment created by large companies no development incurs in terms of employment. Another issue which has an impact of change is that various zones with local features have become major centres in terms of industrial activities (Doldur 2009; Kanbak 2013; Yaşar 2004; Tekeli, Gülöksüz and Okyay, 1976; Tekeli 2011: 86-88; Tümertekin 1997; Sönmez 2016; Tekeli 1975; Tekeli 2010).

Other information that attests to the differences incurred in the spatial distribution pattern of industry in Turkey regard the rate of change in the total employment and enterprise numbers of provinces between 2002 and 2014. Primarily, during this period the share of 26 provinces in Turkey has increased in terms of the number of enterprises while the employment values of 46 provinces have increased. The provinces which have an increased share in terms of enterprise numbers are Istanbul, Gaziantep, Kocaeli, Kayseri, and Sakarya while the provinces with increased numbers in terms of employment are Kocaeli, Bursa, Tekirdağ, Sakarya, Manisa, Gaziantep, Kayseri, Ankara, Konya, and Kahramanmaraș (Figure 2). The provinces in which the number of enterprises has declined the most are Denizli, Ankara, Balıkesir, Aydın, and Izmir, while the provinces for which employment numbers have decreased the most are Istanbul and Denizli (Figure 3). The mentioned increases and decreases are particularly related to 
Figure 4. Change of place in Turkey in terms of the proportion of industry enterprises of provinces between 2002 and 2014 (\%)

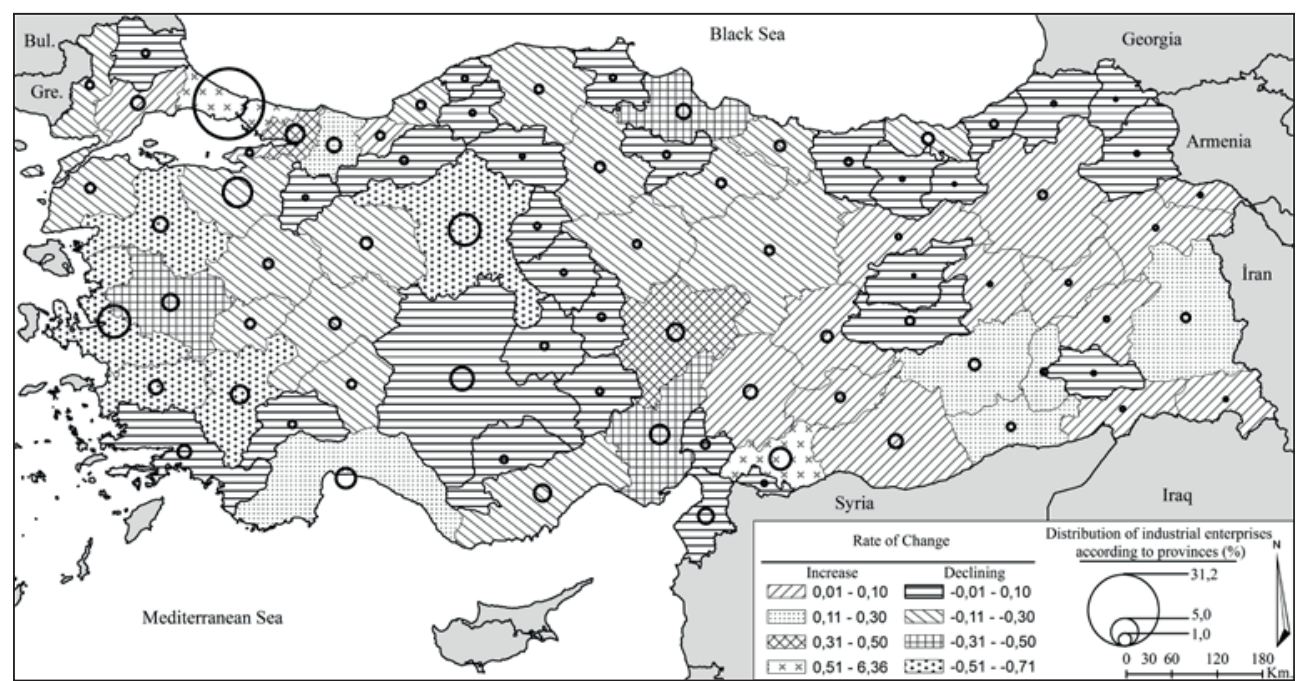

Source: drawn by authors using Turkstat data

Figure 5. Change of place in Turkey in terms of the proportion of industry workers of provinces between 2002 and $2014(\%)$

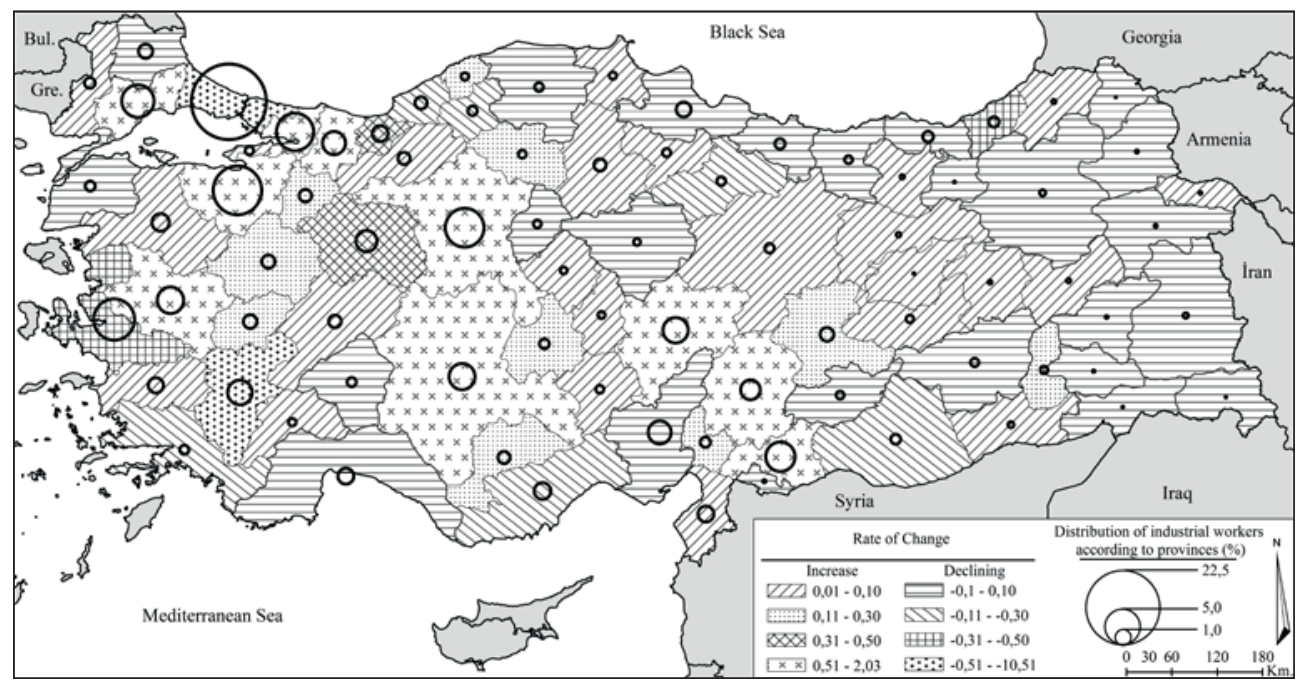

Source: drawn by authors using Turkstat data

the decentralization process taking place in the provinces of Istanbul and Izmir. Furthermore, the rapid increase of organized industrial zones in the regions of East and Southeast Anatolia in the recent past has also had an impact on the change. The desired level in employment is not achieved because even though the number of enterprises is increasing in these zones the facilities are not large and they are not operating on full capacity.

The spatial reflection of all these developments is particularly evident as spatial expansion in terms of employment in industry during the last 12 years. However, this 
expansion has taken place in provinces with a certain industrial tradition in the past years or zones which are in the vicinity of these zones and benefit from externalities to attract the industry in those zones, as well as provinces which have various advantages for industrialization processes. In addition, numerous incentives provided recently for provinces which have failed to generate any kind of success in the field of industrialization in the past process including investments in the form of organized industrial zones have not achieved their full potential. Adequate success has not been achieved in terms of industrial activities. This is supported by the fact that in the years 2002-2014 the number of provinces with less than 10,000 industrial employment numbers receded from 44 to 37 . On the other hand the fact that the number of provinces with over 25,000 employed in industry has increased from 15 to 23 and the number of provinces with over 50,000 employed in industry has increased from 8 to 14 and the number of provinces with over 75,000 employees in industry has increased from 5 to 10 indicates that development has incurred mainly in zones with an industrial history or which are located in the immediate vicinity of such zones.

It is evident that there is a certain concentration in the provinces with more than 75,000 people employed in industry in 2014 which is based on certain characteristics. These characteristics can be compiled under three headings. Firstly, there are the provinces which have collected a significant concentration of industry in the past and which have been industrialized as a result of the decentralization of these zones. Secondly, there are the provinces in which industrial activities have developed historically and in which organized industrial zones and small scale industrial sites have been concentrated in planned zones and therefore have not undergone a decentralization process. Finally, there are the areas which have been industrialized through certain local properties.

In terms of zones which have industrialized as a result of the decentralization of leading industrial provinces Istanbul province has had an impact on the industrialization of Tekirdağ and Kocaeli provinces while Izmir province has been influential in the industrialization of Manisa province. While large enterprises in Istanbul which has undergone a major decentralization process for the past 30-40 years steer toward the zones in the eastern and western directions, the small enterprises take advantage of the externalities presented by the city and continue their tendency to remain within the urban area. This situation causes a decline in employment in the industrial zone in the province while it increases the number of enterprises (Tümertekin 1997; Tekeli 2010; Kanbak 2013; Olcay 2013; Yüzer and Giritlioğlu 2003; Scott 1982). For the past 12 years Istanbul has been one of the provinces with a major decline in industrial employment and the fact that Istanbul ranks 45th in terms of average enterprise size with Tekirdağ west of Istanbul ranking 2nd and Kocaeli province in the east ranking 3rd supports this fact.

Another province which has industrialized as a result of decentralization is Manisa. The decentralization process of Izmir which is a major industrial centre in the region has a significant impact on the basis of industrialization in the province. This has caused both the shifting of existing industrial facilities in Izmir towards Manisa province as well as the continuation of new investments and 4 organized industrial zones ${ }^{2}$ have triggered the industrialization process of the province (Yaşar 2004; Karataş 2006; Ataay 2001; Eraydin 1999).

\footnotetext{
${ }^{2}$ https://osbbs.sanayi.gov.tr/citydetails.aspx?dataID=235 (14.12.2016)
} 
Figure 6. Distribution of number of establishments and workers in manufacturing industry in Turkey (2002)

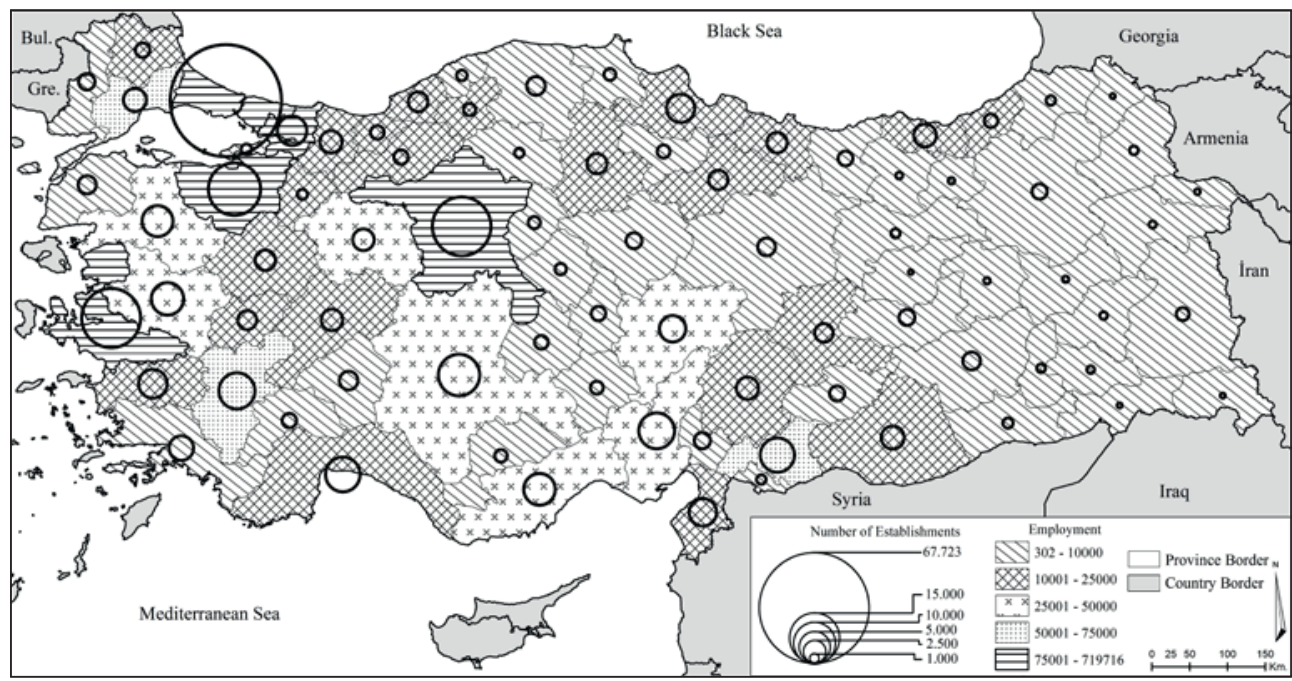

Source: drawn by authors using Turkstat data

Figure 7. Distribution of number of establishments and workers in manufacturing industry in Turkey (2014)

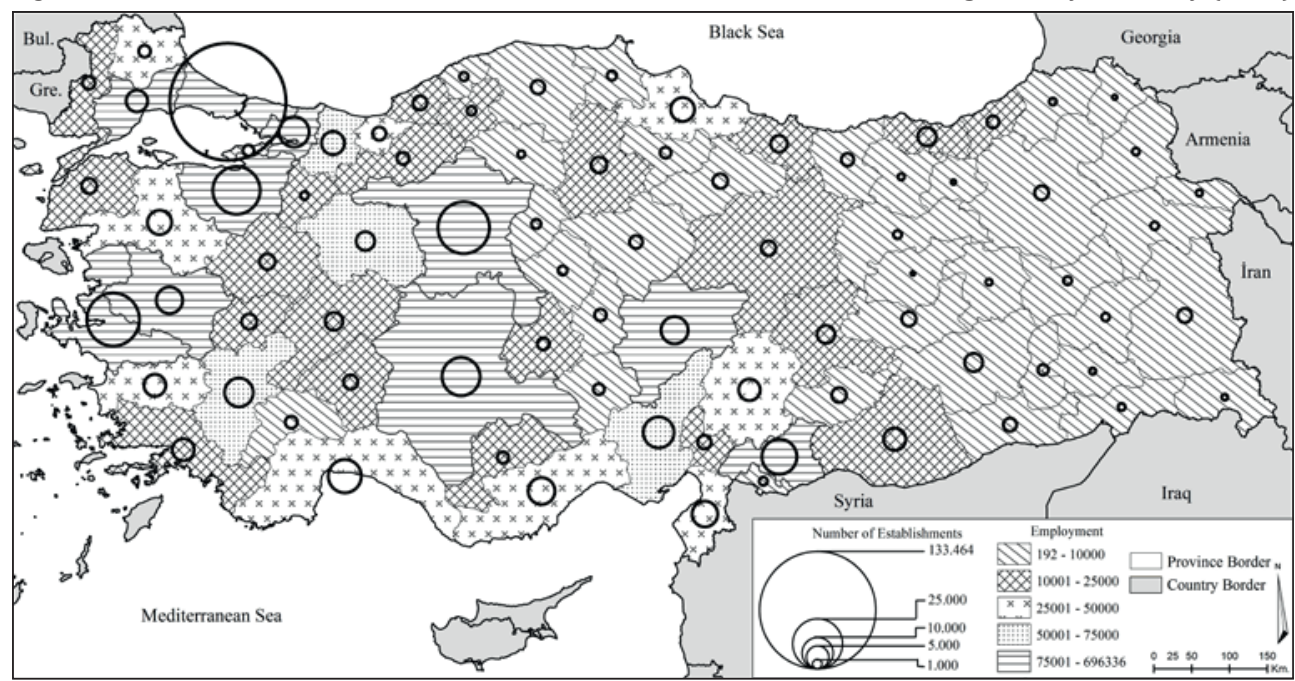

Source: drawn by authors using Turkstat data

Ankara and Bursa are provinces which have prevented existing industries from leaving the provinces by ensuring that most industrial activities are conglomerated in organized industry zones and small scale industry sites and therefore not subjected to decentralization processes. Bursa province is one of the leading provinces which ensured the rapid increase of its industries in Organized Industry Zones. This view is supported by the currently active 13 Organized Industry Zones and 45,000 employees $^{3}$ employed in these zones. Ankara province has ranked in second place after Istanbul through almost all eras with the most industrial facilities and employment. The 
province has avoided decentralization to a major extent by establishing industries in other districts or planned zones adjacent to the city similarly to the application in Bursa province (Bostan, Erdoğanaras and Tamer 2010). The most distinguishing feature differentiating Bursa province from Ankara is the significant alternatives outside Istanbul presented to investors by the province. The circumstances have ensured that Bursa has undergone a more rapid industrialization in the recent past compared to Ankara (Ertürk and Tosun 2009; Eraydın 1999; Öz 2004).

Finally, Konya, Kayseri, Gaziantep, and Denizli are provinces which have been industrialized in accordance with various characteristics they possess. Konya province has undergone a serious industrialization process since the 1980 s due to the rapid progress of the automotive subsidiary industry, as well as the machine manufacturing industry that develops depending on the raw materials based on agriculture (Mutluer 2003; Ünal 2011; Eraydın 1999). The industrialization of Kayseri province has been accelerated by the convenient transport and energy facilities, rich underground resources, cultural accumulation in trade and crafts, putting the exports and investment initiatives to good use as of the 1985, taking advantage of being one of the initial areas for state investments and the continuation of these investments for long years (Ünal 2011; Asiliskender and Özsoy 2010; Yaşar 2004). Gaziantep province is located in an area where industrial activities have displayed less development and is both one of the significant industrial centres of Southeast Anatolia Region, as well as Turkey.The industrialization process of the province has been accelerated due to its prominent tradition of industry which is similar to Kayseri province, the industrialization policies applied after the 1980s, the entrepreneurial nature of the people, initiatives and because it is viewed as the centre of the Southeast Anatolian Project Region (Doğanay 2011; Yaşar 2004; Emmioğlu 2010). Finally, Denizli province has merged its prominent experience in weaving and garment industry with technological developments and launched into a rapid industrialization process after the 1980s. Furthermore, outward looking industrialization which has been applied as of the 1980s has had a significant impact on the industrialization of the province (Eraydin 1999).

Other data that manifest the spatial changes of industrial activities in Turkey are export and import values of manufacturing industry products. During the years 20022014 an increase by $336 \%$ has incurred in the export of manufacturing industry products, as well as an increase by 354\% in imports, and exports have reached 147 billion dollars, while the amount of imports has reached 185 billion dollars. The aforementioned development has been paralleled with spatial change. While the share of the first five provinces in Turkey totalled $86 \%$ in 2002 in terms of export numbers, this figure declined to $77 \%$ in 2014 . Similarly, the share of the first five provinces in Turkey which totalled $90 \%$ in 2002 in terms of imports declined to 86\% during 2002-2014. The change in the rates verified the indicated spatial transformation.

It is evident that some provinces are prominent for the changes which have incurred in total industrial exports and imports during the period of 2002-2014. Furthermore, during this period the share of export values has increased in 64 provinces and in 47 provinces in terms of import figures. Provinces which have observed increased figures for export are Gaziantep, Kocaeli, Ankara, Hatay, Konya, Mardin, and Sakarya while values for import have increased the most in the provinces of Istanbul, Ankara, Kocaeli, Gaziantep, and Manisa (Figure 9). The provinces in which these figures have declined the most in terms of export are Istanbul, Bursa, and Izmir while the declined 
Figure 8. Change of place in Turkey in terms of the proportion of industry exports of provinces between 2002 and $2014(\%)$

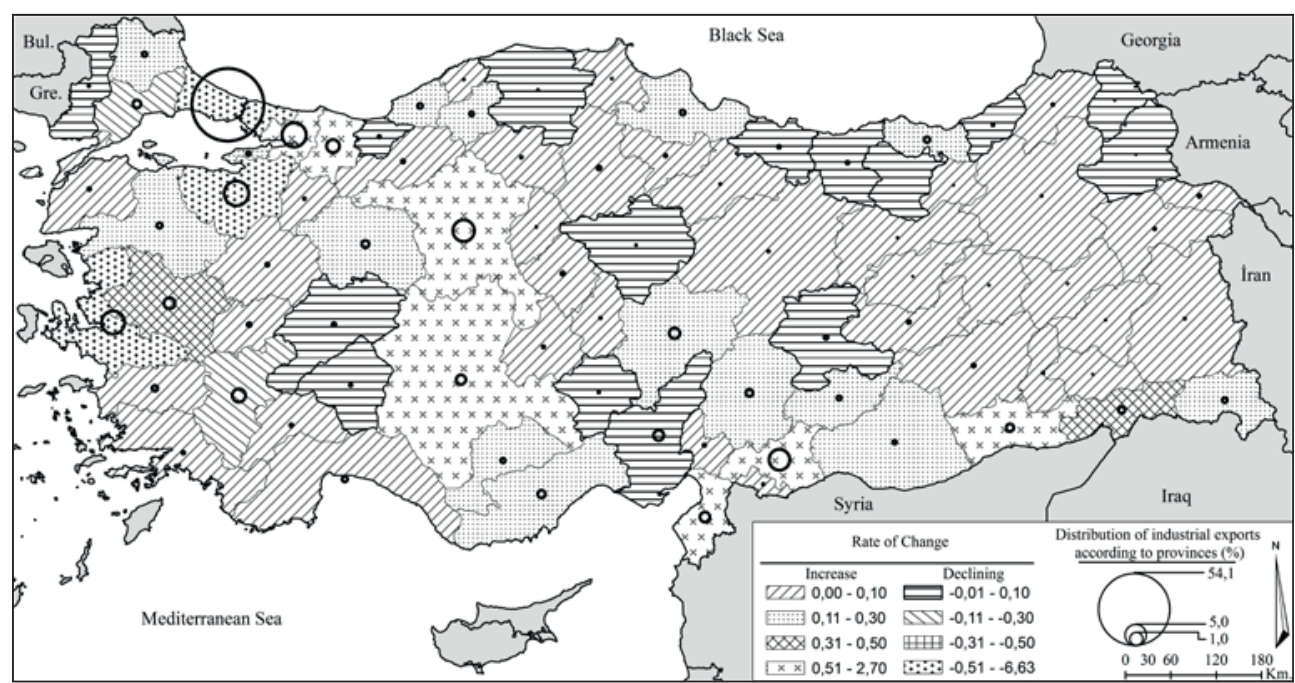

Source: drawn by authors using Turkstat data

Figure 9. Change of place in Turkey in terms of the proportion of industry imports of provinces between 2002 and $2014(\%)$

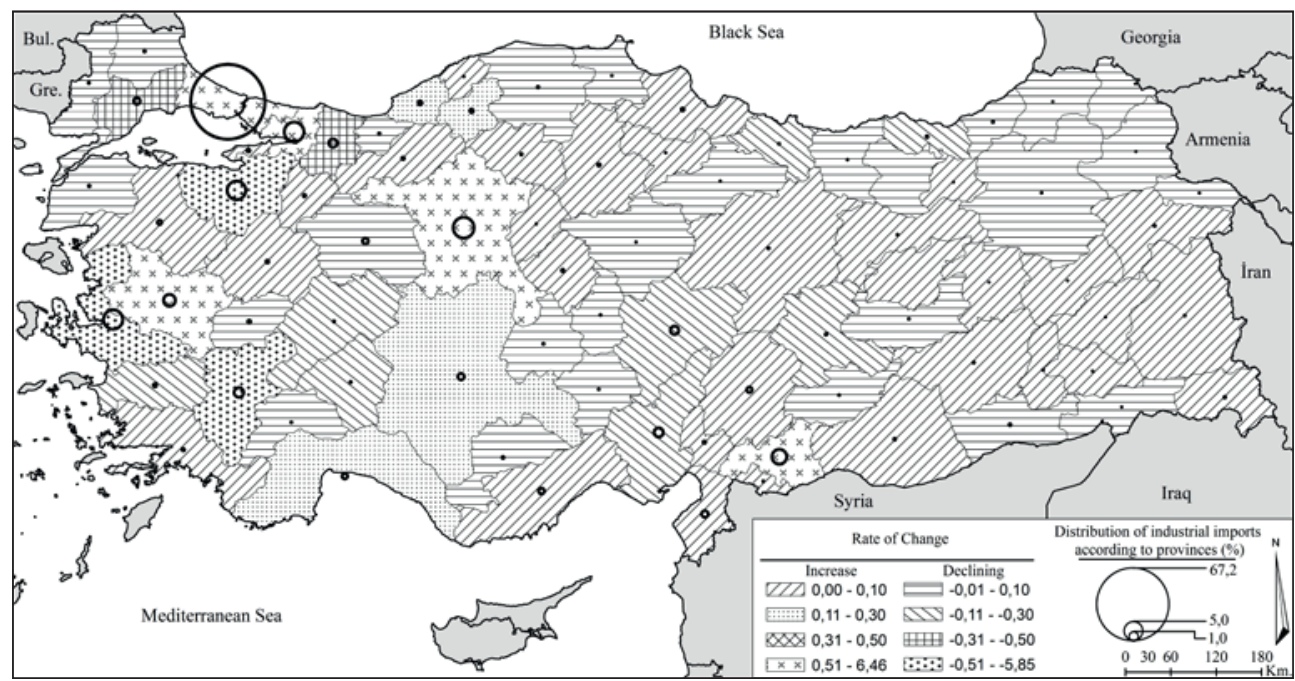

Source: drawn by authors using Turkstat data

figures for imports values are the highest for Bursa, Izmir, and Denizli (Figure 8). The reason for the prominence of increase against decrease in a province is due to the regression in provinces which have previously had a rather large share in the export of manufacturing industry products and the growth trend captured by provinces such as Konya, Gaziantep, Sakarya, and Manisa in the manufacturing industry has a major impact. 
Figure 10. Spatial distribution of export and import of manufacturing industry products in Turkey (2002)

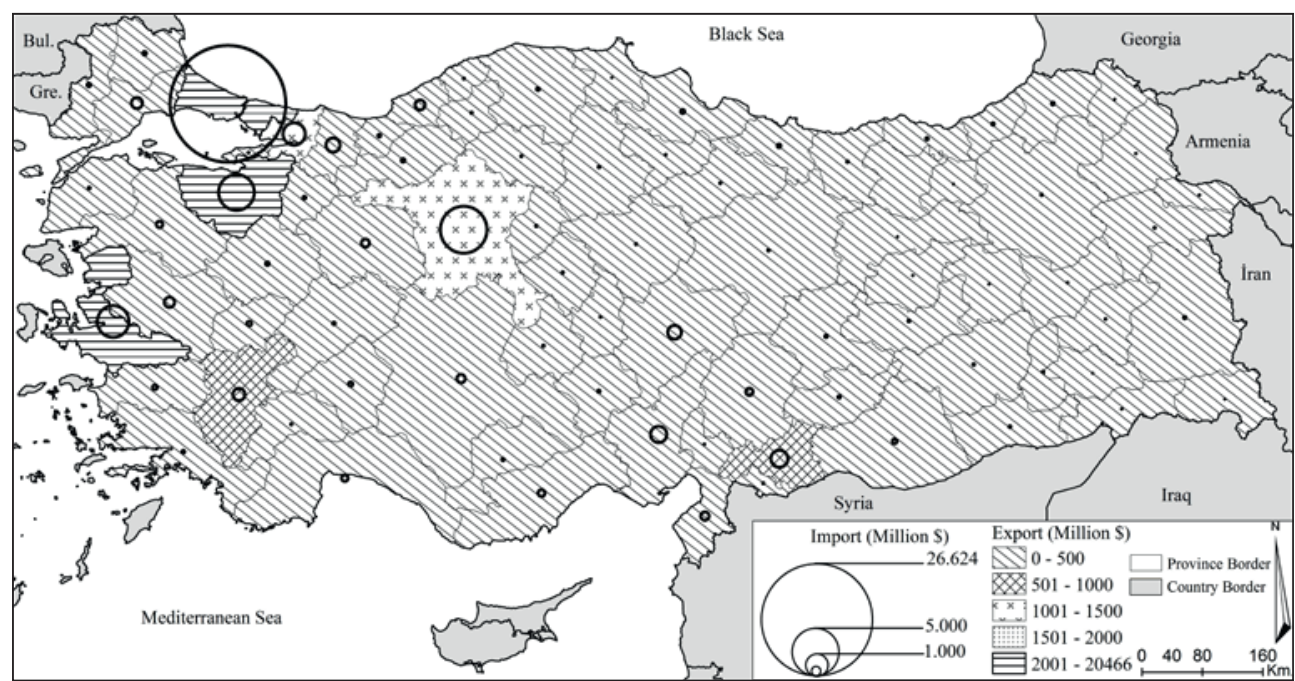

Source: drawn by authors using Turkstat data

Figure 11. Spatial distribution of export and import of manufacturing industry products inTurkey (2014)

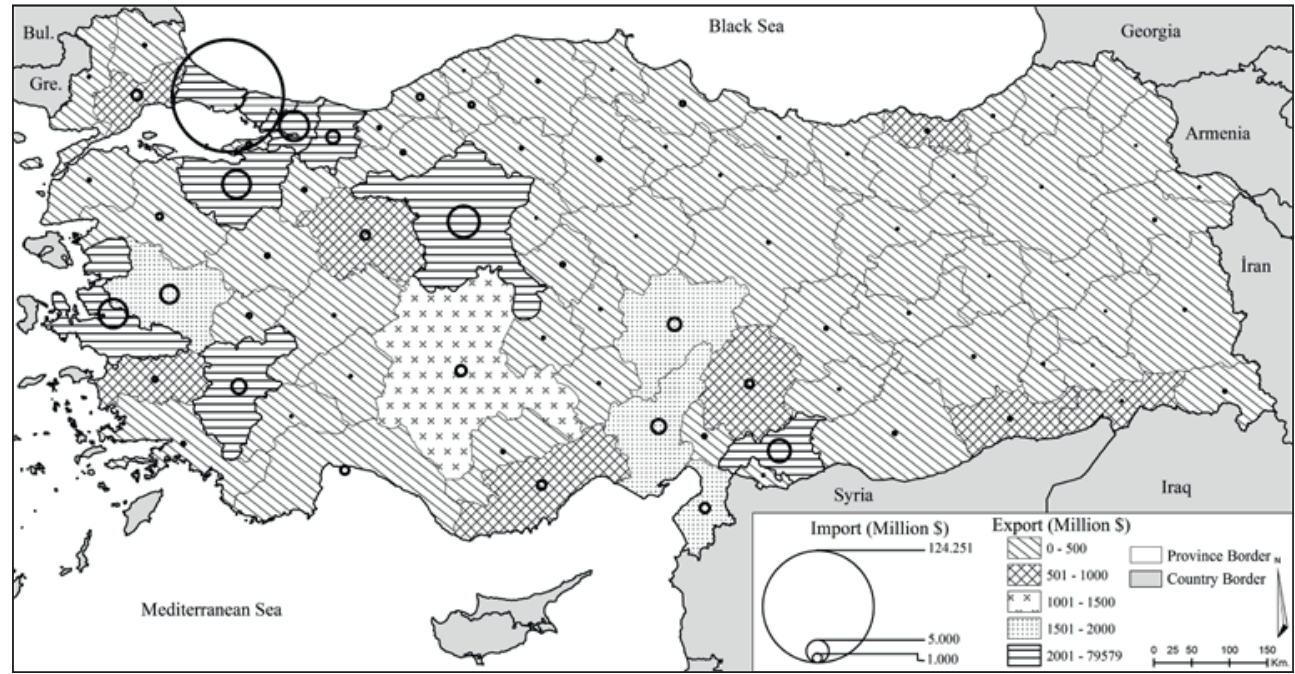

Source: drawn by authors using Turkstat data

There are also various differences in import and export figures and the spatial change of employees in industrial activities. Initially, the export and import values for both 2002 and 2014 are more inclined to cluster than employment values. Furthermore, export and import values of the largest cities in Turkey (Istanbul, Izmir, Bursa, Ankara, Kocaeli) have maintained an important part during both periods. On the other hand the impact of Free Zones is also observed in the spatial distribution of export and import figures (Figures 10 and 11). 


\section{CONCLUSION}

Policies to develop industry have been pursued in Turkey and various regulations have been enacted since the declaration of the Republic. A significant part of the policies which had structures that were able to conform to the circumstances of the era have been successful. The mentioned development is confirmed by the fact that a country without a history in industry has become a country gaining importance on a global scale in terms of added value, production, employment, number of enterprises, and competitiveness analysis criteria.

Another feature which emerges in the development of criteria used in the study of industrial activities is that the enterprises are in a continuous growth trend. The natural result of the growth of enterprises is its contribution to more employment, added value, and production amounts. Furthermore, the industry of Turkey which developed slowly in the first years of the Republic due to the lack of capital has presently established its own capital and many of its companies have started to make investments in major parts of the world.

Equality has also been prioritized in a spatial sense in the development of industrial activities in the country. However, the industrial activities in Turkey have developed in a rather irregular spatial pattern as a significant part of the policies promote the private sector and because state resources are on a level which does not allow investment in all areas. In terms of private entrepreneurship, industry is above all an economic activity which prefers to be established in an area generating high profits. For this reason, during the first years of the Republic, entrepreneurs preferred Istanbul in the Marmara Region, Izmir in the Aegean Region and Ankara in the Central Anatolian Region. However, as of the 1980s a rapid change process started. In the initial phase the necessity of transporting the industrial activities in provinces such as Istanbul and Izmir outside urban areas initiated a rapid decentralization process. At the end of the decentralization process of Istanbul province Kocaeli and Tekirdağ provinces, which are east and west of Istanbul province, started to industrialize. The decentralization of Izmir contributed to the industrialization of Manisa to the east.

Another form of decentralization took place in two large industry centres in the country. Industrial facilities in Bursa and Ankara were transported to planned areas or they developed in these zones and most a decentralization process was not necessary and there was no need to transport industrial facilities outside the provinces.

There are three provinces which have industrialized with various local characteristics other than the seven provinces which have been defined briefly (Konya, Kayseri and Gaziantep). These provinces have industrialized particularly as a result of utilizing state, as well as private sector investments and the raw materials, market and other local characteristics they possess.

Although it is a true assessment that industrial activities in Turkey have currently concentrated in various areas if the current trend prevails it is possible that new areas in terms of industrial activities become prominent in the future. As a matter of fact, likewise to the spatial distribution of employment values, an expansion process into different areas is ongoing. During this process especially the development of transport elements, the high cost of land in central areas, the availability of various incentives for regions which have failed to fulfil their economic potential, the rapid increase of Organized Industrial Zones throughout the country resulting in affordable facilities and 
ready-made infrastructure settings pave the way for the rapid expansion of industrial activities into other areas.

\section{References}

Altıparmak, A. (2002). Türkiye'de Devletçilik Döneminde Özel Sektör Sanayiinin Gelişimi. Erciyes Üniversitesi Sosyal Bilimler Enstitüsü Dergisi, 35-59.

Aoyama, Y., Murphy, J. T., Hanson, S. (2011). Key Concepts in Economic Geography. London: SAGE Publications Ltd.

Ardel, A. (1943). Cumhuriyet Devrinde Endüstri. Türk Coğrafya Dergisi, 316-351.

Asiliskender, B., Özsoy, A. (2010). Cumhuriyet Sonrası Kayseri'de Modernleşme: Mekansal ve Toplumsal Değișim. İTÜ Dergisi, 31-42.

Ataay, F. (2001). Türkiye'de Kapitalizmin Mekânsal Dönüşümü. Praksis, 53-96.

Avcl, S. (1996). Türkiyede Şeker Sanayiinin Kuruluş ve Gelişmesinde Devletin Etkisi. İstanbul Üniversitesi Edebiyat Fakültesi Coğrafya Bölümü Coğrafya Dergisi, 291-302.

Avcı, S. (2000). Türkiye'nin Ekonomi Politikaları ve Coğrafi Sonuçları. Coğrafya Dergisi, 29-70.

Bostan, M., Erdoğanaras, F., Tamer, N.G. (2010). Ankara Metropoliten Alanında İmalat Sanayinin Yer Değiștirme Süreci ve Özellikleri. METU JFA, 81-102.

Celasun, M. (1994). Development Policy and Industrialization in Turkey. International Journal on World Peace, 41-57.

Cillov, H. (1954). Türkiye'de Sanayi İstatistikleri. Íktisat Fakültesi Mecmuası, 176-196.

Cillov, H. (1970). İktisadi İstatistiklerimizde 50 Yıllık Gelişmeler. Íktisat Fakültesi Mecmuasl, 2746.

Clark, E.C. (1992). Osmanlı Sanayi Devrimi. In Osmanlılar ve Batı Teknolojisi Yeni Araștırmalar Yeni Görüşler. İstanbul: İstanbul Üniveristesi Edebiyat Fakültesi Yayınları, 37-52.

Çakmak, H., Erden, L. (2005). Yeni Sanayi Odakları ve Sanayinin Yeni Mekân Arayışları: Denizli ve Gaziantep Örneği. C.Ü. İktisadi ve İdari Bilimler Dergisi, 111-129.

Çam, E. (1984). Türkiye'de Sanayileşmenin Siyasal Gelişme Üzerindeki Etkileri. İktisat Fakültesi Mecmuası, 431-451.

Deloitte (2013). Global Manufacturing Competitiveness Index. INSEAD.

Deloitte (2016). 2016 Global Manufacturing Competitiveness Index. INSEAD.

Deloitte (2016). 2016 Global Manufacturing Competitiveness Index.

DİE (1953). 1950 Sanayi ve İşyerleri Sayımı. Ankara: Devlet İstatistik Enstitüsü Matbaası.

DİE (1968). 1964 Sanayi ve İsyerleri Sayımı: İmalât Sanayii. Ankara: Devlet İstatistik Enstitüsü Matbaasi.

DİE (1969). 1927 Sanayi Sayımı. Ankara: Devlet İstatistik Enstitüsü Matbaası.

DİE (1976). 1970 Sanayi ve İsyerleri Sayımı: İmalat Sanayii. Ankara: Devlet İstatistik Enstitüsü Yayını.

DİE (1984). 1980 Genel Sanayi ve İşyerleri Sayımı İkinci Aşama Sonuçları Küçük İmalat Sanayi. Ankara: Devlet İstatistik Enstitüsü Yayını.

DİE (1985). 1980 Genel Sanayi ve İşyerleri Sayımı İkinci Aşama Sonuçları Büyük İmalat Sanayi. Ankara: Devlet İstatistik Enstitüsü Yayını.

DİE (1997). 1992 Genel Sanayi ve İssyerleri Sayımı Íkinci Aşama Sonuçları I Büyük İmalat Sanayi. Ankara: Devlet İstatistik Enstitüsü Matbaası.

DİE (1997). 1992 Genel Sanayi ve İşyerleri Sayımı İkinci Aşama Sonuçları II Küçük Ölçekli İmalat Sanayi. Ankara: Devlet İstatistik Enstitüsü Matbaası.

Dinler, Z. (2005). Bölgesel İktisat. Bursa: Ekin Kitapevi Yayınları.

Doğan, M. (2013). Türkiye Sanayileșme Sürecine Genel Bakış. Marmara Coğrafya Dergisi, 211231.

Doğanay, H. (2011). Türkiye Ekonomik Coğrafyası. Ankara: Pegem Akademi Yayınları.

Doldur, H. (2009). Bomonti Sanayi Bölgesi'nde Meydana Gelen Değişimler. İstanbul Üniversitesi Edebiyat Fakültesi Coğrafya Bölümü Coğrafya Dergisi, 39-56.

DPT (2003). Türkiye Sanayi Politikası. Ankara.

Emmioğlu, K. (2010). Türkiye'de Sanayileșme Serüveni. İstanbul: Truva Yayınları. 
Eraydın, A. (1999). Sanayiinin Anadolu'da Yaygınlaşması ve Son Dönemde Gelișen Yeni Sanayi Odakları. In 75 Yılda Çarklardan Chip'lere. İstanbul: Tarih Vakfı Yayınları, 257-277.

Ertürk, H., Tosun, E. (2009). Küreselleşme Sürecinde Kentlerde Mekânsal Sosyal ve Kültürel Değișim: Bursa Örneği. U.Ü. Fen Edebiyat Fakültesi Sosyal Bilimler Dergisi, 37-53.

İlgen, A. (2008). 1921 Türkiye Sanayi Sayımları. Ankara: Cedit Neşriyat.

Kalkınma Bakanlığı (2014). The Manufacturing Industry in Turkey. Ankara: Turkey. Member of Deloitte Touche Tohmatsu Limited.

Kanbak, A. (2013). İstanbul Sanayisinin Kocaeli İline Mekânsal Etkileri. AİBÜ Sosyal Bilimler Enstitüsü Dergisi, 275-300.

Karataş, N. (2006). Ege Bölgesi'nde Sanayi Gelişim Süreci ve Mekânsal Yansımaları-İzmir Örneği. Selçuk Üniversitesi Karaman İIBF Dergisi, 191-210.

Karluk, S.R. (1999). Türkiye Ekonomisi Tarihsel Gelişim Yapısal ve Sosyal Değişim. İstanbul: Beta Basım Yayım Dağıtım.

Kerwin, R.W. (1951). Private Enterprise in Turkish Industrial Development. Middle East Journal, 21-38.

Mutluer, M. (2003). Türkiye'de Yeni Gelişen Sanayi Odakları: Denizli Gaziantep Çorum. Ege Cografya Dergisi, 13-27.

Olcay, G.P. (2013). Hazır Giyim Sektörünün Uluslararası Üretim Coğrafyasının Biçimlenme Dinamikleri ve Bu Dinamiklerin İstanbul'a Etkileri. Planlama, 26-34 .

Öz, Ö. (2004). Clusters and Competitive Advantage The Turkish Experience. New York: Palgave Macmillan.

Özbek, Z. (2008). KOBI’lerin Türk Ekonomisine Etkileri. Uluslararası Ekonomik Sorunlar Dergisi, 49-57.

Özgüç, N. (1986-1987). Türkiye'de Sanayi Faaliyetlerinin Gelişmesi, Yapısı ve Dağıllışı. İstanbul Üniversitesi Edebiyat Fakültesi Coğrafya Bölümü Dergisi, 35-70.

Scott, A.J. (1982). Locational Patterns and Dynamics of Industrial Activity in the Modem Metropolis. Urban Studies, 111-142.

Sevgi, C. (1994). Sanayileșme Sürecinde Türkiye ve Sanayi Kuruluşlarının Alansal Dağılımı. İstanbul: Beta Basım Yayım.

Soyyiğit, S. (2010). Türkiye'de İhracata Dayalı Sanayileșme Stratejisi Uygulamaları ve İmalat Sanayii Üzerinde Etkinliği: Nedensellik Analizi (1990-2008). Íktisat Fakültesi Mecmuası, 135-156.

Sönmez, Ö. (2016). İstanbul Merkezli Sanayi Yayılımının Alt Kentlerde Mekansal Etkileri: Tekirdağ Örneği. Yıldız Teknik Üniversitesi Mimarlık Fakültesi E Dergisi, 137-149.

Şahin, H. (2000). Türkiye Ekonomisi. Bursa: Ezgi Kitapevi.

Şener, S. (2005). Türkiye Ekonomisinde İkinci Dönem Liberal İktisat Politikaları. Yönetim Bilimleri Dergisi, 141-148.

Tekeli, İ. (1975). Endüstrinin Arazi Kullanımı Kararlarında Etken Olan Kurumsal Çerçeve. Peyjaz Mimarlı̆̆ $1,49-55$.

Tekeli, İ. (2010). Sanayi Toplumu İçin Sanayi Yazıları. İstanbul: Tarih Vakfı Yurt Yayınları.

Tekeli, İ. (2011). Kent, Kentli Hakları, Kentleșme ve Kentsel Dönüșüm. İstanbul: Tarih Vakfı Yurt Yayınları.

Tekeli, İ. (2011). Kent, Kentli Hakları, Kentleșme ve Kentsel Dönüşüm. İstanbul: Tarih Vakfı Yurt Yayınları.

Tekeli, İ., İlkin, S. (2009). Uygulamaya Geçerken Türkiye'de Devletçiliğin Oluşumu. İstanbul: Bilge Kültür Sanat.

Tekeli, İ., Gülöksüz, Y., Okyay, T. (1976). Gecekondulu, Dolmuşlu, İşportalı Şehir. İstanbul: Cem Yayınevi.

Tekeli, İ., Şenyapılı, T., Güvenç, M. (1991). Ankara'da Sanayi Üretiminin Tarihsel Gelişim Süreci. Ankara: Milli Prodüktivite Merkezi Yayınları.

Temurçin, K. (2004). Isparta İli Ekonomik Coğrafyası. Ankara: Ankara Üniv. Sos. Bil. Enst. Yayınlanmamıs Doktora Tezi.

Temurçin, K. (2004). Isparta İlinde Sanayiinin Gelişimi ve Yapısı. Ankara Üniv. Tür.Coğr.Arş. ve Uyg. Mer. Coğrafi Bilimler Dergisi, 87-104.

Temurçin, K. (2012). Bağcılar (İstanbul) İlçesi'nde Sanayinin Gelişimi ve Yapısı. SDÜ Fen Edebiyat Fakültesi Sosyal Bilimler Dergisi, 105-123. 
Temurçin, K. (2015). Large scale industrial enterprises in Turkish industry: Their structures, characteristics and spatial distribution. Studies of the Industrial Geography Commission of the Polish Geographical Society, 89-112.

Temurçin, K., Aldırmaz, Y. (2014). The Development and The Structure of Industry in The District of Ümraniye, Istanbul. Prace Komisji Geografii Przemysłu Polskiego Towarzystwa Geograficznego, 207-223.

Thailand Board Of Investment. (n.d.). Thailand Electrical and Elektronics.

Tonus, Ö. (2007). Gümrük Birliği Sonrasında Türkiye'de Dıșa Açıklık ve Sanayileșme. Dumlupınar Üniversitesi Sosyal Bilimler Dergisi, 193-214.

TUIK (2007). 2002 Genel Sanayi ve Issyerleri Sayımı. Ankara: Türkiye İstatistik Kurumu Matbaası.

Tümertekin, E. (1959). Türkiye Sanayiinin Coğrafi Temelleri. Türk Coğrafya Dergisi, 16-54.

Tümertekin, E. (1961). İzmir'de sanayi faaliyetlerinin bünyesi ve dağılıșı. Türk Coğrafya Dergisi, $45-62$.

Tümertekin, E. (1997). İstanbul İnsan ve Mekân. İstanbul: Tarih Vakfı Yurt Yayınları.

Tümertekin, E., \& Özgüç, N. (2015). Ekonomik Coğrafya. İstanbul: Çantay Kitapevi.

UNIDO (2013). Industrial Development Report 2013. United Nations Industrial Development Organization.

UNIDO (2015). Industrial Development Report 2016. United Nations Industrial Development Organization.

Ünal, Ç. (2010). Türkiye'de Sanayi: Tarihi Gelişimi ve Bugünkü Yapısı. Erzurum: Mega Ofset.

Ünal, Ç. (2011). Türkiye'de İmalat Sanayinin 1. Düzey Bölgelerindeki Gelişimi ve Karşılaştırılması. Türk Coğrafya Dergisi, 39-54.

Wiener, W. M. (1992). 15-19. Yüzyılları Arasında İstanbul'da İmalathane ve Fabrikalar. In Osmanlılar ve Batı Teknolojisi Yeni Araştırmalar Yeni Görüşler. İstanbul: İstanbul Üniversitesi Edebiyat Fakültesi Yayınları, 53-120.

Yaşar, O. (2002). Sanayi Coğrafyası Açısından Bir Araștırma: Türkiye'de Tarıma Dayalı Sanayiler. İstanbul: Çantay Kitapevi.

Yaşar, O. (2004). Anadolu'da Son Dönemde Sanayileșme Yarışına Katılan İller. Doğu Coğrafya Dergisi, 117-150.

Yücel, T.F. (2015). Cumhuriyet Türkiye'sinin Sanayileșme Öyküsü. Ankara: İșkur Matbaacllık.

Yüzer, A.Ş., Giritlioğlu, C. (2003). Sanayi alanları yeni düzenleme stratejileri - İstanbul örneği. İtüdergisi, 119-127.

\section{Other References and It's Abbreviations}

Central Bank of the Republic of Turkey. World Trade Organisation (WTO).

Devlet İstatistik Enstitüsü (DIE) (State Statistical Institute)

Devlet Planlama Teșkilatı (DPT) (State Planning Organization)

Harita Genel Komutanlığı (General Command of Mapping)

İstanbul Sanayi Odası (Istanbul Chamber of Industry)

Türkiye İstatistik Kurumu (Turkstat) (Turkish Statistical Institute)

\section{Internet References}

http://www.btso.org.tr/?page=bursaeconomy/industrialzone.asp (24.08.2016)

http://www.iso.org.tr/ (24.08.2016)

https://osbbs.sanayi.gov.tr/ (24.08.2016)

http://www.tobb.org.tr/Sayfalar/AnaSayfa.php (14.12.2016)

http://www.bumko.gov.tr/TR,150/doviz-kurlari.html (14.12.2016)

http://www.ekonomi.gov.tr/portal/faces/home/yatirim/serbestBolgeler?_afrLoop $=562582299380927 \& \_$afrWind owMode $=0$ \&_afrWindowId $=$ null $\#$ ! $\% 40 \% 40 \% 3 F_{-}$ afrWind owId\%3 Dnull\%26_afrLoop\%3 D5 $62582299380927 \% 26$ afrWindowMode\%3D0\%26_adf.ctrl-state\%3Dx4k410zme_658 (14.12.2016)

http://www.boi.go.th/upload/content/BOI-brochure\%202015-E\&E_67848.pdf (09.12.2016) 
Kadir Temurçin is working as Prof. Dr. at Süleyman Demirel University, Arts and Sciences Faculty, Department of Geography. Prof. Temurçin was born in Isparta/Turkey in 1973. He graduated from Istanbul University, Faculty of Arts, Department of Geography in 1995. He received an MSc degree in 1998 at the University of Istanbul and a PhD degree in 2004 at the University of Ankara. He has more than 18 years of active research and teaching experience in economic geography, historical geography, geography of crime. Prof. Temurçin is leading major research initiatives in these areas. He has also developed and taught several courses on these topics. The results of his research initiatives include four books: Crime Geography of Turkey-City Public Security Crimes, Sıhhiî - İçtimâî Geography of Turkey, Hamitabat (Isparta) Sanjak, Geographical Survey of Burdur Province Central District, and An Economic Geography Survey: Dinar District. He is also and author of several papers in journals and conference papers, dissertations and technical presentations to various academic and industry audiences.

Yolcu Aldırmaz is working as a research assistant at Süleyman Demirel University, Arts and Sciences Faculty, Department of Geography. Aldırmaz was born in Kars/Turkey in 1989. He graduated from Süleyman Demirel University, Faculty of Arts and Sciences, Department of Geography in 2013. He received an MSc degree in 2015 at the Yüzüncü Yıl University. His research areas are industrial geography, economic development and city-industry relation. He has published several papers in journals and conference papers on industrial geography, economic development and city-industry relation.

\section{Address:}

Süleyman Demirel University

Arts and Sciences Faculty

Department of Geography

32260 Çünür, Isparta, Turkey

e-mail: kadirtemurcin@sdu.edu.tr

e-mail: yolcualdirmaz@sdu.edu.tr 